\title{
TEXTO DRAMÁTICO: POR UMA TEORIA QUE ESTIMULE A LEITURA
}

\author{
Fabiano Tadeu Grazioli
}

\begin{abstract}
RESUMO
Este artigo apresenta reflexões teóricas acerca do texto dramático, sua natureza e sua estrutura - diálogos e rubricas. Apresentam-se, primeiramente, apontamentos que em nada colaboram para a leitura do texto dramático impresso. Em seguida, é apresentado o ponto de vista contrário, trazendo-se estudos que permitem pensar a leitura do referido gênero literário e, mais do que isso, podem incentivar tal prática.
\end{abstract}

PALAVRAS-CHAVE: texto dramático; leitura; teoria.

Para Regina Zilberman, que elogiou a defesa da leitura da dramaturgia nas palavras aqui apresentadas.

\section{Palavras introdutórias}

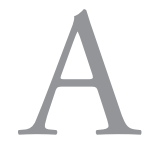

dramaturgia escrita (sinônimo de "teatro dramático", "texto teatral” e "drama” no âmbito deste estudo) não encontra um espaço à altura de sua importância nos cursos de Letras e tampouco nas práticas de leitura promovidas pela escola brasileira. Nem os programas de leitura do Ministério da Educação, ao selecionar seus acervos, dão a devida importância ao gênero dramático, pois, se observado o número de obras dramatúrgicas escolhidas na última seleção para o Programa Nacional Biblioteca na Escola (PNBE) para os anos fnais do Ensino Fundamental e Ensino Médio (2013), notamos que, dos seis acervos de sessenta obras cada, formando um montante de 360 obras, somente quatro obras são do gênero dramático (salvo engano em nossa contagem). 
Há uma descrença generalizada na dramaturgia, pouco se pensa sua leitura, ou seja, a recepção do texto dramático escrito. Mesmo alguns especialistas em literatura infantojuvenil, quando tratam da leitura, sequer lembram de mencionar e motivar a leitura desse gênero. Há pouco tempo, falando a professores sobre esta temática, afirmamos que o único lugar em que a dramaturgia é realmente valorizada é o meio cênico, pois, embora o teatro pós-moderno não se utilize basicamente de uma dramaturgia escrita, muitas são as companhias cujas montagens ainda giram em torno do texto dramático escrito, tendo ele função de matriz, de gerador de todo trabalho. Aliás, os diretores e atores têm muito a ensinar aos professores em relação às práticas de leitura com o texto dramático: eles conhecem as técnicas de leitura dramática, que podem enriquecer as aulas de literatura.

$\mathrm{O}$ artigo que aqui iniciamos possui abordagem bibliográfica e revisa alguns pontos da teoria literária em torno do texto dramático. Inicialmente abordamos a natureza do referido texto, que, se convencionou afirmar, nasce para ser representado, o que, a nosso ver, gera um impasse. Em seguida, passamos a estudar a composição (diálogos e rubricas) do texto dramático e nos indagamos, já no título da seção, se estamos diante de uma estrutura que não permite a leitura. Na terceira seção, em resposta à segunda, buscamos estudos que valorizam a composição do texto dramático, em especial da rubrica, e que apresentam uma abordagem inovadora deste elemento fundamental da dramaturgia. A novidade, na nossa abordagem, é apresentar contrapontos a estudos que em nada contribuem com a leitura e o interesse que um possível leitor de dramaturgia possa vir a ter, seja ele estudante dos cursos de Letras ou de Ensino Médio. Nossas afirmaçôes anteriores sobre a falta de espaço para a dramaturgia em várias instâncias se associam à falta de incentivo que a leitura do texto dramatúrgico encontra, inclusive nos estudos literários. Por isso mesmo, queremos, neste artigo, deixar em evidência autores que em nada colaboram para pensarmos a leitura do texto dramático, seja no âmbito universitário, seja no âmbito escolar, e, principalmente, chamar a atenção para autores que, por meio de suas pesquisas, ampliam de maneira inovadora os estudos literários e ainda contribuem significativamente para encorajar o leitor a ter contato com a dramaturgia escrita, quebrando a barreira que, muitas vezes, nos parece intransponível: a de se formar o leitor do texto dramático impresso, objetivo pelo qual viemos nos empenhando há anos. 


\section{Um texto, dois propósitos e alguns impasses}

O texto dramático é concebido pelos dramaturgos com o destino pré-determinado: projetar o espetáculo cênico. Desse modo, se os gêneros lírico e narrativo não carregam diretamente essa sina, o gênero dramático nasce contendo certos elementos estruturais e estéticos que possibilitam a encenação. Essa característica tem gerado determinada polêmica em torno do texto dramático, visto que ele é considerado uma obra de arte intermediária.

A discussão a respeito desse tema tem suscitado diversas opinióes dos interessados pelo assunto. Carlos Reis é um dos autores a tratar da "problemática" entre texto dramático e representação. Segundo ele, “[...] sem podermos artificialmente separar o que é indestrinçável ou - seja: considerar o texto dramático isolado do espetáculo teatral - a verdade é que os termos em que o modo dramático se concretiza transcendem o plano da leitura e dos estudos literários. (REIS, 2003, p.265).

De acordo com o autor, texto dramático e espetáculo não podem ser analisados isoladamente, o que afasta do primeiro a possibilidade de ser "plenamente" lido e de receber, por parte da teoria literária, um estudo satisfatório. $\mathrm{O}$ mesmo autor, com base na comparação entre os diferentes gêneros literários, argumenta: "Com efeito, se a recepção dos textos líricos e dos textos narrativos se consuma pela leitura, ela é insuficiente para o pleno entendimento do texto dramático, tendo em vista suas virtualidades espetaculares". (REIS, 2003, p. 265).

Com base nesse argumento, o autor atribui aos textos líricos e narrativos o adjetivo "completo", uma vez que têm sua recepção na leitura. O texto dramático, em oposição a esses, seria "pré-pronto", "inacabado", pelo menos até que ocorresse a sua representação. Assim, o autor classifica os dois primeiros como "fundamentalmente literários", na medida em que eles remetem para a dimensão verbal do literário, isto é, literários na condição de textos escritos, a princípio, para serem somente lidos. Já o drama é também classificado como literário, pois também é verbal, mas, como sua finalidade não é somente a leitura, ele é "mais do que isso".

Reis se preocupa com as propriedades literárias e as potencialidades teatrais presentes no texto dramático e, em alguns momentos, remete sua análise para o campo da representação teatral, pois acredita ser impossível conceber o estudo do texto dramático condicionado somente à análise do texto escrito. 
As referências ao processo de montagem, à teoria e à técnica da representação e à sociologia do teatro, segundo ele, são necessárias.

Sergius Gonzaga (2004), embora mencione o texto teatral como fração fundamental do gênero dramático, corrobora o pensamento de Reis:

Ao contrário do que ocorre com o gênero épico e no gênero lírico, a relação dele [do texto dramático] com o público não se dá por meio do simples ato de ouvir e ler, e sim através de sua representação por atores que dialogam e agem. Uma obra (peça) dramática (ou teatral) só adquire vida e revela a sua verdadeira natureza quando se materializa em uma encenação e ou representação. (GONZAGA, 2004, p. 39).

Reis e Gonzaga, por meio de suas consideraçóes, desabilitam o texto teatral de ter sua recepção efetivada pela leitura do texto impresso, diferentemente do que ocorre com a lírica e a narrativa. O pesquisador português entende-o como um texto "incompleto", ao passo que o crítico brasileiro não credita "vida” ao mesmo, se ele não for encenado.

Tais pronunciamentos teóricos, inseridos em um contexto em que se busca oferecer aos alunos informaçóes acerca da natureza do texto dramático, não promovem a sua leitura e repassam para outros campos do conhecimento, como a semiótica teatral, a efetivação desse processo. É fundamental, devido ao hibridismo que percorre as páginas das obras dramatúrgicas - tendo em vista sua natureza específica -, que se considere a possibilidade de o texto ser representado. No entanto, é equivocado restringir o contato com o gênero dramático, como sugerem Reis e Gonzaga, a atividades relacionadas à montagem do texto (direção, interpretação, ensaio), porque limita a leitura aos profissionais da área teatral, o que diminui absurdamente o número de leitores. Se a escola desenvolvesse junto aos alunos conhecimentos da arte cênica, a suposição dos autores não seria tão estranha. Nesse contexto idealizaríamos um trabalho conjunto entre leitura e representação, complementação que possivelmente resultaria na formação de leitores capazes de interagir com o texto dramático e o espetáculo cênico.

A insuficiência dos estudos literários aqui exemplificados a partir de Reis (2003) e Gonzaga (2004) é consequência do apagamento da noção de 
leitura dos estudos literários, mais especificadamente, da crítica literária e da pesquisa em literatura, que Marisa Lajolo tematiza em artigo publicado em 2005. Segundo ela, esses estudos "[...] serão tanto mais produtivos quanto mais se detiverem nas diferentes formas de interação entre autores, obras e públicos no bojo de diferentes tradiçôes. [...] Numa primeira mirada, essas mediaçóes e interaçóes articulam-se de diferentes formas às condiçóes de leitura - públicas e privadas - disponíveis na sociedade. (LAJOLO, 2005, p. 87, grifo da autora).

A partir de Lajolo, podemos afirmar que os estudos literários não possuem flexibilidade suficiente para dar conta da leitura dos diferentes gêneros. A singularidade da teoria frente à pluralidade dos textos gera estudos incompletos, que terminam por fragmentar conhecimentos que poderiam muito bem (se observadas desde o princípio as "diferentes formas de interação entre autores, obras e públicos") existir sem divisão. E a escola, encarregada da "educação literária” do indivíduo e da formação de leitores críticos e plurais, procura cumprir essa tarefa utilizando-se desses estudos.

Outro índice da ineficiência da teoria literária frente aos textos é o fato de que as mais diversas manifestaçóes artísticas costumam se abastecer de argumentos e ideias geridos nas obras literárias dos mais diversos gêneros. Nesse sentido, é ultrapassado considerar o texto dramático como o único passível de ser atualizado por outros sistemas artísticos, considerando-se que estes podem operar na perspectiva de atualizar, em sua linguagem, textos dos diferentes gêneros. ${ }^{1}$ Frente a essa característica tâo presente na arte contemporânea, a teoria literária deveria reelaborar seus pressupostos, com o objetivo de, por meio deles, promover a leitura da literatura e uma compreensão mais ampla do texto dramático.

À perspectiva teórica de Carlos Reis e Sergius Gonzaga, podemos associar muitos outros autores, mas nossa escolha revela a manutenção dos seus conceitos em diferentes níveis de ensino, pois Reis geralmente compóe a bibliografia básica de muitas disciplinas da graduação em Letras, o que não é distinto de Gonzaga em relação ao Ensino Médio. É importante considerar também que ambos tratam do assunto de modo bastante genérico, sendo o

1 Podemos citar, mais especificamente, os romances e contos que são adaptados para o cinema, o teatro e a televisão. Quanto aos textos teatrais, é válido lembrar que eles também são "atualizados" pelo cinema e pelos programas de televisão. 
texto teatral um tema secundário dentro dos estudos literários aos quais eles se dedicam efetivamente. Contudo, isso não impede que sejam lidos e determinem o conhecimento de professores e alunos.

Um grupo restrito de autores trata do dilema da representação de modo menos problemático, trazendo às teorias elementos que, mesmo implícitos, possibilitam pensar a leitura desse gênero. De tal grupo faz parte Sábato Magaldi, que deixa uma abertura para tanto, ao afirmar que "será mais fecundo pensar a arte dramática na totalidade de seus elementos" (MAGALDI,1965, p. 11). Assim, o autor náo elimina a possibilidade de se ler o texto teatral, embora considere uma leitura mais ampla aquela que o relacione aos elementos que a ele se integram na representação cênica. Ao citar Baty, Magaldi reafirma essa possibilidade:

O texto é a parte essencial do drama. Ele é para o drama o que o caroço é para o fruto, o centro sólido em torno do qual vêm ordenar-se todos os outros elementos. [...] E do mesmo modo que, saboreando o fruto, o caroço fica para assegurar o crescimento de outros frutos semelhantes, o texto, quando desaparecem os prestígios da representação, espera numa biblioteca ressuscitá-los um dia. (BATY apud MAGALDI, 1965, p. 11).

O autor atribui ao texto dramático o lugar que lhe é de direito no contexto geral da atividade teatral, destacando-o como progenitor dos demais elementos cênicos. Embora ele não viabilize diretamente a leitura desse gênero, as considerações que tece não eliminam a possibilidade de fazê-lo. Usando a analogia do fruto, cujo caroço fica esperando a fertilização, tal qual o texto, que aguarda a "ressurreição", o crítico permite inferir que o texto teatral pode ser atualizado por meio da leitura, ou seja, a sua "ressurreição" pode ser viabilizada pela recepção do texto escrito.

A esse panorama podemos agregar as consideraçóes de Massaud Moisés, que, mesmo não aconselhando o leitor a esquecer que se trata de um texto literário distinto dos demais, propóe uma análise que se concentra no texto como literatura: "Visto que é o texto que importa, as notaçôes referentes às demais artes que porventura aparecerem serão postas à parte: o texto interessa- 
rá como um romance ou um conto”. (MOISÉS, 1969, p. 212). A partir dessa colocação, inferimos que o autor não limita a leitura do gênero tendo em vista sua natureza específica, e viabiliza a sua recepção por meio da leitura do texto escrito, colocando-o a par dos demais gêneros.

Além disso, Moisés (1969) singulariza-se por articular ao texto teatral um componente fundamental da leitura: a imaginação. Afirma ele:

Decerto, uma narrativa qualquer implica que o leitor ponha em funcionamento seus dotes de fantasia, mas os vários auxiliares de que lança mão o ficcionista (como a dissertação, a narração e a descrição) lhe simplificam a tarefa. O leitor de teatro, falho de tais expedientes, vê-se obrigado a movimentar todas as turbinas de sua imaginação, sob pena de permanecer impermeável no texto. (MOISÉS, 1969, p. 212).

Diferentemente do autor, creditamos ao texto teatral uma construção não menos complexa que a dos demais gêneros, ideia que aprofundamos ao tratar sobre a rubrica. Mas, com relação à imaginação, Moisés (1969) atribui a esta faculdade humana função tẫo indispensável que admite que a sua falta ou o seu uso de modo superficial podem ter como resultado uma leitura insatisfatória, ou seja, uma leitura que não proporciona ao leitor um contato significativo com o texto: "Assim, o leitor arquiteta na imaginação um palco em que transcorre a fábula da peça. Ao fazê-lo, está apto a estabelecer a segunda destrinça da análise do texto teatral, referente à sua representabilidade, seu potencial de tensão dramática comunicável ao leitor e a comunicar ao espectador”. (MOISÉS, 1969, p. 211).

$\mathrm{O}$ autor é duplamente singular em sua colocação. Em meio a tantos outros que julgam que o texto teatral é capaz de se atualizar somente no palco, ele vê a possibilidade de o leitor fazê-lo em um palco imaginário, montado mentalmente, que serve de local para a narrativa processada pelo texto, e credita ao leitor a aptidão de interagir com a linguagem cênica a partir da leitura. Para Moisés (1969), o potencial da tensão dramática pode ser recuperado pelo leitor do texto do mesmo modo que pelo espectador da encenação.

A partir das consideraçóes expostas, podemos afirmar que a leitura do texto teatral, frente aos outros gêneros, é um exercício de imaginação vital, 
pois a natureza do gênero dramático lhe atribui uma particularidade, a qual associa a possibilidade de encenação às possibilidades de interpretação do leitor. $\mathrm{O}$ fato de essa possibilidade estar latente, gritante em sua composição, exige que sua leitura "dê conta" de atualizar mentalmente toda a narrativa e imaginá-la, devendo o leitor apostar nessa faculdade humana para realizar uma leitura significativa do texto teatral.

Desse modo, ao tratar da imaginação, Moisés (1969) introduz a figura do leitor no contexto dos estudos literários, de onde ele ficou afastado por um longo período de tempo e, no caso do texto teatral, continua afastado até hoje. Contudo, é importante ressaltar que essa inserção se dá porque o autor busca entender o processo de leitura do texto dramático a partir de suas particularidades.

\section{O diálogo e as rubricas: uma composição que não quer a leitura?}

O que há de mais claro na leitura do texto teatral é a sua composição, pois percebemos imediatamente que se trata de um texto composto pelas falas das personagens e pelas informaçôes que contextualizam essas falas. De acordo com o que apresentamos na sequência desta seção, os autores e críticos literários se referem a esses dois elementos nomeando o primeiro simplesmente como "fala" e o conjunto delas como "diálogo", e o segundo como "rubrica" ou "didascálias".

A estrutura duplamente elaborada do texto dramático tem suscitado, ao longo dos tempos, dois posicionamentos distintos dos interessados pelo assunto. Seja dentro do círculo de análise semiótica do teatro ou no campo da literatura dramática, a supervalorização dos diálogos frente às rubricas ${ }^{2}$ tem sido, além de um divisor de águas entre os teóricos, um tema gerador de polêmica.

Esses posicionamentos antagônicos terminam por aparecer nas consideraçôes teóricas que chegam até os diversos níveis de ensino e, desse modo, tal qual o caso apresentado anteriormente, a respeito da natureza do texto teatral, as formulações teóricas que ganham espaço no ensino da língua e da literatura terminam, muitas vezes, por prestar um desserviço à promoção da leitura do texto dramático.

2 A alternativa contrária - a supervalorização das rubricas frente aos diálogos - não é sinalizada pelos autores pesquisados. O máximo que alguns autores buscam é uma importância equilibrada entre os dois elementos. 
É sabido que uma personagem em cena pode falar a outra personagem diretamente, ao espectador ou, ainda, a si mesma. João Domingues Maia (1995) afirma que essas possibilidades permitem distinguir as réplicas, o aparte e o monólogo, respectivamente. Essas categorias compartilham da mesma essência, como podemos perceber na definição que Luiz Paulo Vasconcellos, em seu Dicionário de Teatro $(1987)^{3}$, dá à fala: "Em termos gerais, a ação de falar. Em teatro, a parte do diálogo de cada um dos personagens”. (VASCONCELLOS, 1987, p. 89). Ao assim se pronunciar, o autor nivela as categorias referidas anteriormente, pois trata-se, nos três casos, do ato de se pronunciar verbalmente. Referindo-se ao "diálogo", por sua vez, aponta para o conjunto das falas que são, portanto, as partículas menores desse conjunto:

Processo de comunicação verbal entre duas ou mais pessoas. [...] um dos dois processos básicos de comunicação e expressão do personagem, o outro sendo o comportamento. [...] É, pois, graças ao diálogo que a ação dramática caminha, ao mesmo tempo em que se torna compreensível através da exposição e objetivos que a constituem. (VASCONCELLOS, 1987, p. 68).

O autor, ao atribuir à dialogação e ao comportamento da personagem o movimento progressivo da narrativa, destaca o que há de mais elementar na arte dramática, seja com relação ao texto, seja com relação às encenaçóes que ele venha a projetar: a ação, elemento que fundamenta o teatro nesses dois âmbitos. Ela constitui o elemento nuclear do teatro e sua importância está expressa na própria palavra "drama”, que, em grego, significa ação. Quanto à conceituação de "diálogo", percebemos que o autor é sucinto, tal qual o formato de sua obra (dicionário) exige, mas lista a característica e a função básica desse elemento: a expressão verbal das personagens e a articulação do processo de comunicação pelo viés da palavra enunciada no palco ou no texto impresso.

3 Esse dicionário é fruto de anos de pesquisa do autor, que é pesquisador e professor aposentado do Departamento de Artes Dramáticas da UFRGS, e de seus alunos, na bem-sucedida tentativa de reunir mais de seiscentos verbetes e defini-los de forma correta e substancial. Substancial porque o autor utiliza-se das melhores fontes bibliográficas para definir esses vocábulos, não atribuindo a eles somente o significado, mas procurando trazer ao leitor aspectos da história do teatro, das técnicas de direção e atuação, entre outros. 
A par dos "diálogos" e das "falas", temos o outro elemento da estrutura do texto teatral, que é chamado por Vasconcellos de rubrica. Definindo a expressão, o autor afirma que se refere a:

Qualquer palavra escrita que não faça parte do diálogo. Essas palavras podem ser tanto o nome da personagem diante de cada fala, quanto a descrição da personagem, do cenário, do figurino, ou indicaçôes de entrada e saídas de cenas, sugestão de marcação, ou, ainda, comentários explicativos relativos ao estado de espírito dos personagens ao enunciar as palavras do texto [...]. (VASCONCELLOS, 1987, p. 172).

João Domingues Maia (1995), ao conceituar as partes que compóem a peça teatral, nomeia os textos que se intercalam com os diálogos como didascálias. Para o autor, elas se referem a "[...] qualquer indicação cênica concernente ao ambiente, à época, aos costumes, aos objetos, aos gestos dos atores, às entonaçóes, à lista das personagens etc., normalmente destacadas em maiúsculas, grifos ou entre parênteses [...]”. (MAIA,1995, p. 251).

Vasconcellos e Maia apresentam ideias convergentes em relação às rubricas ou didascálias, pois atribuem a elas funçôes praticamente idênticas: inserir os diálogos no contexto específico do qual eles são resultado, por meio de informaçóes de naturezas diversas.

Ao utilizar o termo "didascálias", Maia (1995) acaba por relembrar, implicitamente, detalhes curiosos e importantes da história do texto dramático, já que o termo empregado pelo autor se associa ao teatro grego. De acordo com Luiz Fernando Ramos (1999, p. 24),

[...] didaskalias, em grego antigo, é um substantivo feminino que pode significar instruçáo pura e simplesmente, ou, num sentido mais preciso, as instruçóes dadas pelo poeta dramático aos atores e a indicação de suas respectivas partes na representação. Pode ser também o ato de treinar e ensaiar o coro, de produzir o drama, ou o catálogo de um espetáculo, onde constem o nome dos escritores, a data das apresentaçóes e os títulos das compilações de textos utilizadas. 
As afirmações de Ramos (1999) relacionam-se às apresentadas anteriormente, porém ampliam a função das didascálias, à medida que conferem a elas, mais do que já atribuíram Vasconcellos e Maia, o papel de designar o processo de ensaio, produção e comunicação dos detalhes da encenação, como datas e textos a serem representados. A expressão designaria todo o processo de atualização dos diálogos, compreendendo setores que, atualmente, tratam de fazê-la separadamente: orientar os atores, ensaiar, produzir (artisticamente e financeiramente) e divulgar o espetáculo. Desse modo, percebemos que as "instruçóes”, às quais se refere Ramos (1999), ultrapassam o limite dos comandos escritos, característica que está relacionada ao teatro grego, em que "[...] quem mediava a relação entre o dramaturgo e o coro era o didaskalos, que poderia ser também, apenas, um instrutor de crianças. [...] é apenas um intermediário entre o dramaturgo, que quase não escreve rubricas, e os atores do coro. Ele interpreta e traduz as aspirações do dramaturgo". (RAMOS, 1999, p. 24).

Com relação aos textos do período descrito pelo autor - as tragédias do período clássico -, Ramos (1999, p. 25) acrescenta que

[...] não continham outras indicaçôes que não as de entrada e saída e, com alguma frequência, o nome das personagens antes das falas. Muitas vezes, nem o nome da personagem que estava falando aparecia nos textos originais em grego. Isso porque era hábito dos gregos do período clássico saudarem um interlocutor, quando este se aproximava, chamando-o pelo nome. Assim, o raro leitor deste texto numa sociedade que ainda convivia fortemente com a tradição oral, ou [...] o didaskalos, não era esclarecido sobre a personagem a que cabia aquela fala por meio de uma rubrica, mas pela fala da personagem que fazia a saudação.

Afirmamos, com Ramos (1999), que as informaçóes que hoje buscamos nas rubricas estavam, no caso das tragédias gregas, imiscuídas nos diálogos, e o didaskalos e os raros leitores das tragédias se esforçavam em operar essas transformaçôes na encenação ou na imaginação. Nesse sentido, os diálogos, além de movimentarem a narrativa no sentido da progressão dramática, segundo afirmamos a partir de Vasconcellos (1987), condensavam as instruçóes para a 
atuação dos atores na encenação. Ramos desenvolve um trabalho aprofundado a respeito da rubrica, o qual exploramos mais intensamente na sequência desta seção, oportunidade em que relacionamos suas consideraçôes teóricas à promoção da leitura do gênero dramático.

Carlos Reis (2003), ao tratar da estruturação do texto dramático, admite a existência de dois textos que se articulam na configuração de um único: um texto principal e um secundário. Ao texto principal, segundo o autor, cabe a enunciação da personagem, sua dialogação e a expressão verbal da mesma. $\mathrm{O}$ adjetivo principal revela o destaque que, para Reis, o discurso da personagem tem no texto teatral e, consequentemente, na sua representação. Quanto ao texto secundário, a ele é atribuída a função de informar as características da personagem, sua situação na cena em questão, a entonação do seu discurso e como a personagem deve proceder no desenvolvimento da cena ou do diálogo. Também cabe ao texto secundário a indicação a respeito do espaço onde se realiza a ação da peça, do ato ou da cena. Para Reis esse texto seria, na verdade, um subtexto, e, mesmo que tenha tantas finalidades, desempenha função secundária frente aos diálogos.

A evidente supervalorização dos diálogos frente às rubricas que Reis revela a partir de suas formulaçóes, do mesmo modo que por meio da nomenclatura que seleciona - texto principal e texto secundário -, encontra correspondência nas consideraçôes do autor Sergius Gonzaga (2004), mesmo que este nem chegue a abrir um espaço em seu texto para desenvolver esse tópico. Ao tecer consideraçóes a respeito do processo de transposição do texto dramático para o palco, comenta discretamente: "Os atores emprestam ao texto, composto basicamente de diálogos, seu corpo, seus gestos, seu olhar e sua voz, mostrando, desse modo, ao público, os personagens que encarnam”. (GONZAGA, 2004, p. 39).

Ainda de acordo com esse autor, as demais informaçóes que o texto dramático pode conter são irrisórias: ao referir-se ao mesmo, ele nem as cita. $\mathrm{O}$ "esquecimento" do autor não deixa que, em sua pequena incursão pelo tema, o desprestígio do segundo texto ${ }^{4}$ frente aos diálogos passe despecebido: a expressão "basicamente", utilizada por ele, já nos revela a inferioridade que credita à rubrica.

4 Optamos por usar, neste caso, a nomenclatura que Reis (2003) utiliza para designar a rubrica, por dois motivos: por náo sabermos como Gonzaga se refere a elas e por compreendermos que o espaço que esse autor dá ao elemento em questão é secundário, tal qual verificamos em Reis. 
Observamos também uma contradição na posição de Gonzaga, tendo em vista toda a citação transcrita anteriormente. Os atores só poderão "emprestar ao texto" sua performance corporal se esse processo for mediado pelas rubricas. É importante lembrar que mesmo os textos gregos do período clássico (que, segundo Ramos, ocultavam nos diálogos as informaçóes necessárias à sua articulação no palco) exigiam o trabalho de um intermediário. Este, conhecedor do texto e das intençóes do escritor, conduzia os atores nas encenações, o que nos faz pensar na inevitável contextualização por meio de informações, sejam elas escritas ou instruções orais. Quanto aos referidos textos, hoje, vale ressaltar que muitas vezes eles chegam até nós por meio de traduçôes que procuram inserir ao menos as rubricas que facilitam a leitura.

A importância do texto principal é reiterada por Reis, que compara texto teatral e narrativo, articulando, nessa comparação, a figura do narrador:

[...] não se manifesta aqui [nas rubricas], ao mesmo nível textual do discurso dos personagens, uma voz estruturante e organizadora da ação, correspondendo àquela que na narrativa é a voz do narrador. É certo que, como leitores, temos acesso aos dois textos; trata-se, portanto, de uma situação, por assim dizer, provisória e circunstancial, ainda aquém do que deverá ser o completamento e a plena articulação de ambos os textos referidos no espetáculo teatral. (REIS, 2003, p. 269-270).

Segundo o autor, a divisão do texto teatral em principal e secundário desaparece na representação, o que o leva a considerar, enquanto somente lido, um texto provisório. No espetáculo, o segundo texto desaparece, ou melhor, transforma-se na sua propriedade visual: tudo aquilo que o espectador não escuta, mas vê, desde os aspectos do cenário e do figurino até a entonação da voz e a atuação corporal. Ainda que a tensão entre diálogos e rubricas pareça diminuir ao se tratar da encenação, percebemos que o autor considera a leitura do texto dramático uma ação incompleta, "aquém” do que é a atualização promovida pelo espetáculo. Essa inferioridade também é expressa quando Reis destitui a rubrica de sua função narrativa e organizadora do discurso literário dramático. $\mathrm{Na}$ verdade, esses dois equívocos estâo imbricados: o primeiro configura-se como consequência do segundo, uma vez que o autor deixa 
transparecer que está empenhado em transferir para o campo da encenação os impasses que a teoria literária tem dificuldade de resolver.

\section{As rubricas conduzem o leitor: uma leitura para além dos diálogos}

A estrutura do texto dramático é resultado de sua natureza específica, o que faz com que ele contenha, virtualmente, as ideias que serão concretizadas pela linguagem teatral. Desse modo, aquilo que é literatura dramática torna-se teatro no momento da representação. Anatol Rosenfeld (2002, p. 29), discorrendo a respeito dessa transformação, afirma que

[...] a função narrativa, que no texto dramático se mantém humildemente nas rubricas (é nelas que se localiza o foco), extingue-se totalmente no palco, o qual, com os atores e cenários, intervém para assumi-la. Desaparece o sujeito fictício dos enunciados - pelo menos na aparência, visto as próprias personagens se manifestarem diretamente através do diálogo, de modo que mesmo o mais ocasional "disse ele", "respondeu ela" do narrador torna-se supérfluo.

A partir de Rosenfeld (2002), podemos afirmar que a encenação teatral possui uma narrativa visual, que é a transposição para o plano do palco de, pelo menos, duas categorias de informaçôes: os elementos cênicos (cenários, luzes, figurinos, adereços) e o comportamento dos atores. Ambas recuperam, aos olhos do espectador, grande parte do trabalho do "narrador" do texto dramático, atualizando as informaçôes contidas nas rubricas. Ao assim supormos, é fundamental ressaltar que o autor está tratando de uma das possibilidades de atualização daquilo que se encontra registrado na peça teatral escrita: a representação. A outra possibilidade, a leitura do texto que antecede essa operaçáo, embora não seja a tônica do comentário de Rosenfeld, é articulada por ele ao considerar o texto dramático possuidor de uma estrutura narrativa completa, na medida que afirma que as rubricas sustentam o sujeito fictício dos diálogos, ou seja, o narrador.

Diferentemente de Reis (2003), que afirma ser inferior a força narrativa das rubricas em relação ao texto narrativo, não podendo ser caracterizada 
como uma voz estruturante e organizadora da ação, Rosenfeld (2002) permite-nos inferir que a rubrica constitui fração fundamental da estrutura do texto de dramaturgia, pois o foco da narração ali se encontra. Quanto à maneira "humilde" como o autor afirma que a rubrica conduz a narração, acreditamos que se trata, no caso de alguns textos, da existência de informaçóes simples e contidas, com pouco ou nenhum detalhamento, mas que, mesmo assim, conservam a função de organizar e conduzir a narrativa, tornando-se fundamental na composição do texto teatral.

Percorrendo as páginas das obras dramáticas de diferentes autores e épocas, encontramos, junto a algumas peças, rubricas objetivas; junto a outras, amplas e detalhadas indicaçóes cênicas que não apenas fornecem as informaçôes elementares e estruturantes do texto, mas também se empenham em descrever e narrar situações mais completas, sugerindo climas e circunstâncias, e, em muitos casos, indicando até nuances da estética teatral em que o texto deve ser concebido.

$\mathrm{Na}$ lista de autores que desenvolveram pesquisas a respeito das funçóes da rubrica, encontramos Luiz Fernando Ramos, cujos estudos reafirmam a sua importância na efetivação da leitura do gênero dramático. A tese de Ramos (1999) é a de que nas rubricas estariam inseridas, junto às instruções que se mostram vitais para a materialização cênica do texto, outras que garantem a manutenção de aspectos fundamentais da estética cênica pensada pelo dramaturgo, de acordo com o que o autor entende: "A ideia é revelar este tipo de rubrica não só como potencial instauradora de uma certa materialidade cênica, mas também como espelho de um estilo particular de engendrar espetáculos, e como índice de uma poética cênica específica". (RAMOS, 1999, p. 182).

Para demonstrar a presença daquilo que chama de "poética de cena" nas rubricas, o autor analisa minuciosamente a dramaturgia de Samuel Beckett ${ }^{5}$ e, a partir dela, declara: "Em sua escrita dramática [...] a rubrica será tão importante quanto o diálogo, pois refere-se a uma desejada ocupação tempo-espacial do palco que se revelará imprescindível a cada espetáculo efetivo que se apresente". (RAMOS, 1999, p. 61).

5 Samuel Beckett (1906-1989), escritor irlandês que se tornou mundialmente famoso com a peça Esperando Godot, apresentada pela primeira vez em 1953. Em 1969, Beckett recebeu o Prêmio Nobel de Literatura. Influenciou uma geração de dramaturgos como Harold Pinter, Tom Stoppard e Edward Albee. 
A presença e a valorização das rubricas na obra de Beckett garantem a manutenção da forma de encenação "desejada" por ele. Guardariam elas, segundo Ramos, a expectativa do autor com relação às montagens de seu texto, de acordo com o que verificamos nesse exemplo:

As chamadas indicaçóes cênicas têm, pois, em Beckett, desde o primeiro texto, peso fundamental na sua dramaturgia, sendo já imprescindíveis na transposição deste texto para o palco. Isso fica ainda mais claro na parte final da Nota sobre a montagem de cenário e sobre ação marginal, em que detalha, exatamente, sua expectativa sobre o que seja essa ação marginal em cada um dos atos. É uma instrução importante para quem monta Eleuthéria pois, como já se disse, estas açôes "marginais" não aparecerão indicadas como rubricas no corpo do texto referente à ação principal, ou seja, não estão imiscuídas entre os diálogos. (RAMOS, 1999, p. 63, grifo do autor).

Ramos sistematiza seu estudo analisando particularmente alguns textos do dramaturgo irlandês. A respeito da não observação das indicaçóes cênicas da peça Esperando Godot, o pesquisador declara com firmeza: "Quem ignora completamente as rubricas da peça deixa de encenar Esperando Godot de Samuel Beckett, já que, mais do que sugerir açóes acessórias, algumas rubricas indicam ações fundamentais para que se consume o arco de ação proposto pelo dramaturgo". (RAMOS, 1999, p. 65, grifo do autor).

A garantia da perpetuação da obra de Beckett não está, segundo Ramos, na manutenção dos diálogos, e sim na observação das coordenadas lançadas pelas rubricas. A "poética de cena" que irá receber e contextualizar os diálogos deverá ser respeitada, sob pena de, se assim não for, se extinguir a essência da obra do dramaturgo.

Embora trate da leitura do texto dramático atrelada à sua concretização cênica, o mesmo autor considera essa particularidade de alguns textos teatrais uma ocorrência literária: "A poética cênica que se quis revelar tem, de fato, existência puramente literária, o que não enfraquece a hipótese de que a virtualidade do espetáculo a que ela remete esteja aí representada”. (RAMOS, 1999, p. 159). 
Do lugar em que desenvolve seus estudos (diretor teatral e professor de Teoria e História do Teatro), o autor discorre a respeito da existência "puramente literária" da "poética de cena" e reafirma a possibilidade de esse recurso orientar a versão cênica do texto teatral. No caso da utilização que fizemos aqui, a partir de suas consideraçóes teóricas, a afirmação de que a "poética de cena" recai, primeiramente (e diretamente), no texto escrito vem ao encontro de nossa argumentação, de acordo com o que explicitamos no desenvolvimento deste estudo.

Podemos relacionar as consideraçóes teóricas de Ramos aos estudos de Elen de Medeiros (2006), que se dedicou a estudar as Tragédias Cariocas de Nelson Rodrigues ${ }^{6}$ e investiga a constituição e consistência dramática de suas peças, por meio da análise das personagens, dos diálogos e das rubricas. Tratando deste último elemento, a autora afirma:

Mais do que um fator de integralização do texto cênico, a abordagem nas rubricas que Nelson faz é literária, lançando mão de recursos tâo literários quanto aqueles utilizados nos diálogos. Ou seja, além da ambientação, descrição dos figurinos e caracterização das personagens, fatores comuns dentro das rubricas, o dramaturgo desenvolve nelas um texto paralelo à ação da peça, evidenciando uma característica altamente literária. Isso se dá devido aos recursos linguísticos e ao processo narrativo evidente nas rubricas [...]. (MEDEIROS, 2006, p. 145).

A partir de Medeiros, afirmamos que as rubricas do autor são elaboradas especialmente para serem lidas, o que revela a existência de um trabalho elaborado em torno desse elemento: "Interessante observar a preocupação do dramaturgo em especificar os detalhes do espaço cênico, sem, no entanto, se despreocupar com a linguagem literária. Isso porque, ao descrever toda a cena, a linguagem que o autor utiliza é semelhante àquela desenvolvida na peça, tentando manter uma unidade de sentido [...]”. (MEDEIROS, 2006, p. 144).

6 Trata-se do conjunto ao qual pertencem oito peças do dramaturgo brasileiro, a saber: A falecida (1953), Perdoa-me por me traires (1957), Os sete gatinhos (1958), Boca de ouro (1959), O beijo no asfalto (1961), Otto Lara Resende ou Bonitinha, mas ordinária (1962), Toda nudez será castigada (1965) e A serpente (1978). 
Outra aproximação entre os autores em questão é a possibilidade de a rubrica apontar para determinados elementos do campo da linguagem teatral, característicos do dramaturgo. Nesse sentido, Medeiros (2006, p. 142) afirma que

[...] um elemento de grande valia no teatro de Nelson Rodrigues, muito bem aproveitado, principalmente no aspecto de inovação cênica, são as rubricas. [...] E, em se tratando de dramaturgia nacional, Nelson Rodrigues se destaca pelo uso das rubricas, uma vez que ali está evidente a maneira como o autor imaginou a encenação de sua peça.

O modo particular como Nelson Rodrigues imaginou as cenas e que transparece nas rubricas demonstra, segundo Medeiros, que o autor utilizou tal recurso também para trazer inovações no campo cênico. Mas essas informaçôes não ficam claras e visíveis somente para os atores e diretores, pois "a composição literária dessas rubricas indica a preocupação do dramaturgo em montar, em um primeiro momento, o cenário da peça e deixá-lo claro para o seu leitor." (MEDEIROS, 2006, p. 146).

As rubricas podem, na medida em que comportam o narrador das peças, como afirma Rosenfeld (2002), apresentá-lo com características que sinalizam uma posição crítica do narrador perante as situaçôes retratadas nas peças e ainda serem literárias e reveladoras dos estilos de encenação próprios de seus autores.

O narrador presente nas rubricas de Nelson Rodrigues é, de acordo com Medeiros (2006), rigoroso no sentido de se mostrar atento e observador, e explora uma visão crítica do tema ou da situação proposta, deixando transparecer o estilo preciso e irônico do dramaturgo.

\section{Algumas palavras para o fechamento}

Acreditamos ser pertinente apresentar conclusóes em alguns momentos do texto, oportunidades em que assim o fizemos. Mas cabe pontuarmos algumas questões sobre cada seção do artigo, momento em que não perderemos de vista questôes relacionadas à dramaturgia e à leitura.

$\mathrm{Na}$ primeira seção, tratamos dos impasses que alguns teóricos criam ao creditarem à leitura do texto dramático impresso um processo incompleto. 
Contudo, autores como Moisés (1969), do mesmo modo que Magaldi e Baty (1965), deveriam ganhar espaço nas aulas de Teoria Literária e Literatura Dramática das universidades, para auxiliarem na formação de professores que vão atuar em uma conjuntura educacional que ainda não pensa seriamente a leitura em termos teóricos e práticos, e em que a leitura do gênero dramático é praticamente esquecida. Cabe ressaltar que Moisés, em estudo da década de 1960, já lançava um olhar que até hoje não foi assimilado e compreendido por muitos estudiosos. Olhar sensível e coerente para um gênero que precisa de um mirada especial quando se trata de pensar a sua teoria e a sua leitura.

Ao tratarmos da composição do texto teatral, na segunda seção, demos ênfase às rubricas e ao modo como alguns estudiosos percebem sua presença na estrutura do texto dramático. Após o levantamento que fizemos, somos levados a afirmar que o processo de recepção de textos dramáticos que busque oferecer aos leitores em formação o texto dramatúrgico e que utilize como suporte teórico as considerações de Reis (2003) e Gonzaga (2004) sobre as rubricas está fadado ao insucesso. Os encaminhamentos teóricos desses autores promovem orientaçóes equivocadas com relação à leitura do texto de dramaturgia: a exclusão do gênero dramático do grupo dos diferentes textos que poderiam fazer parte desse processo e, tendo em vista a possibilidade de o leitor chegar ao texto, a realização de uma leitura incompleta. A primeira consequência negativa é resultado dos comentários que avaliam a recepção do gênero dramático por meio da leitura do texto escrito como insatisfatória. A segunda é patrocinada pelas considerações que diminuem a importância das rubricas frente aos diálogos, o que pode levar o leitor a ignorá-las.

Desse modo, afirmamos que procedimentos como os apresentados por Reis (2003) e Gonzaga (2004) terminam por estimular a rejeição do gênero dramático nos diferentes níveis de ensino ou, na melhor das hipóteses, por encaminhar, de modo equivocado, o encontro entre leitores e peças teatrais.

Em relação às consideraçóes de Vasconcellos (1987) e Maia (1995) sobre as rubricas, podemos afirmar que elas são pontuais - e, uma vez que, neste estudo, nos propusemos a avaliar as consideraçóes teóricas sobre o texto dramático em sua relação com a leitura, podemos considerá-las aparentemente imparciais. No entanto, ao pensarmos na possibilidade de seus fundamentos teóricos orientarem os estudos de dramaturgia e a leitura do referido gênero nos diversos níveis de ensino, atribuímos a essa neutralidade um caráter positivo, pois, ao 
sistematizarem suas ideias, sem discutirem a importância de um ou outro elemento (diálogo ou rubrica) na macroestrutura do texto dramático, os autores colaboraram, discretamente, para a promoção da leitura do referido gênero.

Frente à explanação realizada na última seção, podemos inferir que os pressupostos de Ramos (1999) e Medeiros (2006), principalmente se colocados em contraste com as consideraçoóes de Reis (2003) e Gonzaga (2004), são fomentadores da leitura do texto dramático. As posições positivas desses autores diante da estrutura do drama, sobretudo no que se refere à função e importância das rubricas, apontam para uma leitura completa e satisfatória do texto teatral.

À medida que a estrutura do texto teatral permite que uma leitura adequada do gênero seja realizada, também podemos inferir que, a partir das colocações de Ramos (1999) e Medeiros (2006), a recepção do gênero dramático pode evidenciar, mesmo pelo viés do texto impresso, uma interação significativa com a linguagem cênica. Já havíamos elucidado essa hipótese ao tratarmos da natureza deste gênero. Agora, as consideraçóes dos autores consultados terminam por confirmá-la, pois ambos analisam textos em que as rubricas, além das funçôes básicas deste elemento, estão contaminadas pelos métodos e maneiras muito próprias de os autores pensarem a encenação.

É nesse ponto que reside a possibilidade de uma interpretação equivocada dos pressupostos de Ramos (1999) e Medeiros (2006), pois se poderia pensar que, pelo fato de as rubricas determinarem o enfoque do espaço cênico como linguagem, elas e, consequentemente, o texto teatral somente interessariam ao leitor preocupado em atualizar no palco o referido texto (atores, diretores, encenadores). Contudo, cabe ressaltar que desencaminhar a leitura do texto teatral e subestimar a importância da rubrica nesse processo, tal como fizeram Gonzaga (2004) e Reis (2003), é negar a possibilidade de se articular, por meio da imaginação do leitor, uma experiência estética duplamente rica: o desenrolar da narrativa dramática e a interação com a montagem cênica, conduzida pelo leitor no "palco imaginário" projetado em sua mente, segundo nos ensinou Massaud Moisés, ainda em 1969.

\section{Referências}

GONZAGA, Sergius. Curso de literatura brasileira. Porto Alegre: Leitura XXI, 2004. 
LAJOLO, Marisa. A leitura em Formação da literatura brasileira de Antonio Cândido. Desenredo. Universidade de Passo Fundo, Passo Fundo, v.1, n. 1, p. 76-91, semestral, 2005.

MAGALDI, Sábato. Iniciação ao teatro. Rio de Janeiro: Ao livro técnico, 1965. MAIA, João Domingues. Literatura: textos e técnicas. São Paulo: Ática, 1995. MEDEIROS, Elen de. Nelson Rodrigues e as Tragédias Cariocas: um estudo das personagens. $S B U$, http://libdigi.unicamp.br, 16/10/2015.

MOISÉS, Massaud. Guia prático de análise literária. São Paulo: Cultrix, 1969. RAMOS, Luiz Fernando. O parto de Godot e outras encenaçóes imaginárias: a rubrica como poética de cena. São Paulo: Hucitec/Fapesp, 1999.

REIS, Carlos. O conhecimento da literatura. Porto Alegre: EDIPUCRS, 2003. ROSENFELD, Anatol. Literatura e Personagem. In: de ficção. Série Debates: Literatura. São Paulo: Perspectiva, 2002. VASCONCELLOS, Luiz Paulo. Dicionário de teatro. Porto Alegre: L\&PM, 1987.

\title{
DRAMA TEXT: FOR A THEORY THAT STIMULATES THE READING
}

\begin{abstract}
This article presents theoretical reflections about the drama text, its nature and its structure - dialogues and headings. First, this research shows some thoughts and notes that does not collaborate for the reading of printed drama text. Then, the opposite view is presented, with studies that allow us to think about the reading of the referred literary genre - and, more than that, can encourage this practice.
\end{abstract}

KEYWORDS: drama text, reading, theory.

Recebido em: 09/09/2015 Aprovado em: 09/03/2016 